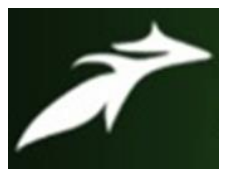

Rashmi Dave et al, International Journal of Advances in Agricultural Science and Technology,

Vol.7 Issue.11, November-2020, pg. 91-99

ISSN: 2348-1358

Impact Factor: 6.057

NAAS Rating: 3.77

\title{
Study on Knowledge of Tribal Women Regarding Poultry Production
}

\author{
Rashmi Dave; Rajshree Upadhyay; Dhriti Solanki; Lekhu Kumar \\ DOI: 10.47856/IJAAST.2020.v07i11.013
}

\begin{abstract}
The present study was undertaken to assess the knowledge of tribal women regarding poultry production entrepreneurial activity. The study was conducted in Southern Rajasthan. Three KVKs viz. Banswara, Dungarpur and Udaipur were selected on the basis of highest concentration of tribal population. 19 tribal women from the each KVK were taken randomly to make a total sample of 57 respondents. Questionnaire and interview schedule were used to collect data. Frequency, percentage, mean percent scores, mean weighted scores, paired test and F-test were used to analyze the data.

Keywords- Tribal women, Knowledge, Poultry production, Entrepreneurial activity
\end{abstract}

\section{Introduction}

Women in a tribal society play a vital role in their social, cultural, economic and religious ways of life and are considered as an economic asset in the society. They contribute significantly to the management of their natural, social and economic resources. But their contribution has not been identified fully and acknowledged. Knowledge is an understanding of something such as facts, information, descriptions which is acquired through experience or education by perceiving, discovering or learning. Knowledge can refer to a theoretical or practical understanding of a subject. Knowledge as a body of understood information possessed by an individual is one of the important components of adoption behavior. It has even been considered by many extension scientists as prerequisite for adoption. In this context, KrishiVigyan Kendra (KVK) is one of the leading institutions devoted to the welfare of the farming community. The idea behind KVK is to influence the production system with social justice, the starting point being the neediest and deserving section of the society, the weaker sections, tribal farmers, small and marginal farmers, agricultural laborers, drought and flood-affected farmers and so on. KVK is a district level institution engaged in the transfer of latest agricultural technologies to the end users for bridging 


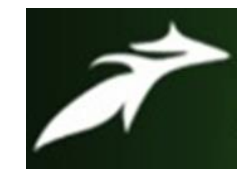

Rashmi Dave et al, International Journal of Advances in Agricultural Science and Technology,

Vol.7 Issue.11, November-2020, pg. 91-99

ISSN: 2348-1358

Impact Factor: 6.057

NAAS Rating: 3.77

the gap between production and productivity. It works through partnership mode with allied departments and agencies. Presently, there are 706 KrishiVigyanKendras in the country. The KVK has been assigned five important functions, viz., On-farm testing, frontline demonstrations, capacity development of farmers and extension personnel, work as knowledge and resource center and provide farm advisories. In addition KVKs produce quality technological products (seed, planting material, bio-agents, livestock) and make it available to farmers, organize frontline extension activities, identify and document selected farm innovations and converge with ongoing schemes and programs within the mandate of KVK. Thus KVKs are the institutions committed to vocational training, transfer of latest technologies, on-farm research and serving as a lighthouse for farm families.

\section{Material and Methods}

The Present study was conducted in Southern Rajasthan which includes Banswara, Dungarpur, Chittorgarh, Udaipur, Rajsamand, Pratapgarh and Sirohi districts. In Southern Rajasthan, major concentration of tribal population is in four districts i.e. Banswara, Dungarpur, Pratapgarh and Udaipur. Out of these, three KVKs viz. Banswara, Dungarpur and Udaipur were selected for the present study. Selected KVKs in Southern Rajasthan were promoting various entrepreneurial activities. In view of the objective of the study poultry production was selected for the present study. A sample of 19 tribal women were selected randomly from each KVK to form a sample of 57 tribal women. To fulfill the objective of the study, two tools one questionnaire and the interview schedule was developed. Interview technique was used for data collection from tribal women. Frequency, percentage, mean percent scores, mean weighted scores, paired $t$ test, and F-test were used to analyze the data.

\section{Result and Discussion}

Poultry production is a viable business activity and has got immense scope for growth in India. It has taken a quantum leap in the last four decades, emerging from an entirely unorganized and unscientific farming practice to a commercial production system with 


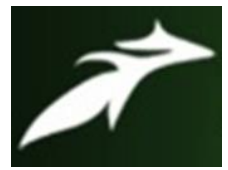

Rashmi Dave et al, International Journal of Advances in Agricultural Science and Technology,

Vol.7 Issue.11, November-2020, pg. 91-99

ISSN: 2348-1358

Impact Factor: 6.057

NAAS Rating: 3.77

technological interventions. Poultry is making a significant contribution to improve the economy of rural and urban population as it requires less area and gives high return than any other animal husbandry and agriculture activities. It does not only supplement the income of producer by way of eggs, meat and compost but also helps in increasing the employment avenues. An effort was made to know the knowledge of the respondents about different poultry production practices under four major heads viz. breeding, feeding, health care and management practices (Table 4.9).

\section{Breeding}

The production of commercial chicks does not happen by chance, but is the outcome of systematic and time consuming scientific breeding. Selection of eggs for hatching is done by seeing size and weight of eggs. Perusal of data in Table 1 vividly present that the respondents were well aware about the selection of eggs with MPS of 92.9.

Table 1: Extent of knowledge of the respondents regarding poultry production

\begin{tabular}{|c|l|c|c|c|c|}
\hline \multirow{2}{*}{ S. No. } & \multicolumn{1}{|c|}{ Components } & \multicolumn{4}{c|}{ Mean Per cent Score } \\
\cline { 3 - 6 } & & Banswara & Dungarpur & Udaipur & Total \\
\hline I & Breeding & & & & \\
\hline 1 & Improved breeds & 68.4 & 63.15 & 68.4 & 66.65 \\
\hline 2 & Ratio of male female & 63.15 & 47.36 & 36.84 & 49.12 \\
\hline 3 & Selection of eggs for hatching & 100 & 94.73 & 84.21 & 92.98 \\
\hline 4 & $\begin{array}{l}\text { Recommended no of eggs kept for } \\
\text { hatching }\end{array}$ & 73.68 & 52.63 & 47.36 & 57.89 \\
\hline 5 & Hatching period & 73.68 & 57.89 & 63.15 & 64.91 \\
\hline 6 & Clutch size & 73.68 & 63.15 & 52.63 & 63.15 \\
\hline
\end{tabular}




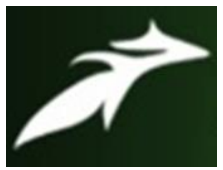

Rashmi Dave et al, International Journal of Advances in Agricultural Science and Technology, Vol.7 Issue.11, November-2020, pg. 91-99

ISSN: 2348-1358

Impact Factor: 6.057

NAAS Rating: 3.77

\begin{tabular}{|c|c|c|c|c|c|}
\hline 7 & Age of egg laying & 68.42 & 57.89 & 52.63 & 59.65 \\
\hline 8 & Age of cock for breeding & 73.68 & 63.15 & 52.63 & 63.15 \\
\hline II. & Feeding & & & & \\
\hline 1 & Recommended quantity of feed & 68 & 57.89 & 57.89 & 61.26 \\
\hline 2 & Ingredients of poultry feed & 46.31 & 36.84 & 40 & 41.05 \\
\hline 3 & Use of feeders & 21.1 & 10.52 & 10.52 & 14.05 \\
\hline 4 & Timely starting of feed to chicks & 37.0 & 36.84 & 31.57 & 35.14 \\
\hline III. & Health Management & & & & \\
\hline 1 & Common diseases of poultry & 31.57 & 26.31 & 31.57 & 29.82 \\
\hline 2 & Means by which diseases spread & 0 & 0 & 0 & 0.00 \\
\hline 3 & $\begin{array}{l}\text { Measures to protect poultry birds from } \\
\text { diseases }\end{array}$ & 100 & 94.73 & 89.47 & 94.73 \\
\hline 4 & $\begin{array}{l}\text { Measures to protect poultry birds from } \\
\text { internal parasites }\end{array}$ & 100 & 100 & 100 & 100.00 \\
\hline 5 & $\begin{array}{l}\text { Measures to protect poultry birds from } \\
\text { external parasites }\end{array}$ & 100 & 100 & 100 & 100.00 \\
\hline 6 & $\begin{array}{llll}\text { Season mainly } & \text { responsible } & \text { for } \\
\text { poultrydiseases } & & \\
\end{array}$ & 100 & 100 & 100 & 100.00 \\
\hline IV. & Management & & & & \\
\hline 1 & Essential requirements of poultry shed & 100 & 78.94 & 86.84 & 88.59 \\
\hline
\end{tabular}




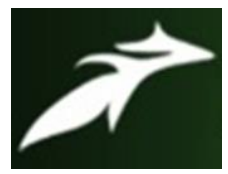

Rashmi Dave et al, International Journal of Advances in Agricultural Science and Technology, Vol.7 Issue.11, November-2020, pg. 91-99

ISSN: 2348-1358

Impact Factor: 6.057

NAAS Rating: 3.77

\begin{tabular}{|c|l|c|c|c|c|}
\hline 2 & Standard size of poultry shed & 36.84 & 31.57 & 36.84 & 35.08 \\
\hline 3 & Cleaning in poultry shed & 100 & 100 & 100 & 100.00 \\
\hline 4 & Material used for bed in shed & 68.42 & 68.42 & 63.15 & 66.66 \\
\hline 5 & Material used when bed gets wet & 26.31 & 26.31 & 21.05 & 24.56 \\
\hline IV. & Health Care & & & & \\
\hline
\end{tabular}

Nirbheek and Pratapdhan are the improved breeds of poultry. Hatching period of poultry is 21 days and 8-10 eggs should be kept under broody hen for hatching. Clutch size (Clutch size refers to the number of eggs laid in a single brood by a nesting pair of birds) of 10-15 eggs can be taken from these improved breeds. They usually begin laying eggs at 21 weeks of age and age of cock for breeding is 6-7 months. Knowledge possessed by the respondents in these aspects ranged between $57.85-66.65$ MPS.

\section{Feeding}

Modern feeds for poultry consists largely of grain, protein supplements such as soybean oil meal, mineral supplements and vitamin supplements. The quantity of feed, and the nutritional requirements of the feed, depends on the weight and age of the poultry, their rate of growth, their rate of egg production, the weather (cold or wet weather causes higher energy expenditure) and the amount of nutrition the poultry obtain from foraging. This results in a wide variety of feed formulations. The substitution of less expensive local ingredients introduces additional variations. Healthy poultry require a sufficient amount of protein and carbohydrates, along with the necessary vitamins, dietary minerals, and an adequate supply of water. Poultry convert feed into food products quickly and efficiently. Data in the table clearly show that respondents possessed knowledge about recommended quantity of poultry feed to the extent of 61.26 per cent, whereas respondents possessed average knowledge about ingredients of poultry feed (41.05 


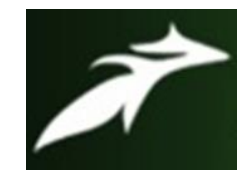

Rashmi Dave et al, International Journal of Advances in Agricultural Science and Technology, Vol.7 Issue.11, November-2020, pg. 91-99

ISSN: 2348-1358

Impact Factor: 6.057

NAAS Rating: 3.77

MPS) and timely start of feeding to chicks after $48 \mathrm{hrs}$ (35.14 MPS). Knowledge about feeder was poor among the respondents i.e. only to the extent of 14.5 per cent.

\section{Health care}

Poultry vaccines are widely applied to prevent and control contagious poultry diseases. Their use in poultry production is aimed at avoiding or minimizing the emergence of clinical disease at farm level, thus increasing production. Vaccines and vaccination programmes vary broadly in regard to several local factors (e.g. type of production, local pattern of disease, costs and potential losses) and are generally managed by the poultry industry. In the last decade, the financial losses caused by the major epidemic diseases of poultry (Avian influenza and Newcastle disease) have been enormous for both the commercial and the public sectors. Thus, vaccination should also be applied in the framework of poultry disease eradication programmes at national or regional levels under the official supervision of public veterinary services. In this regard knowledge was assessed and it was found that that respondents possessed correct knowledge about medication of poultry birds to protect them from internal and external parasites and more attention to poultry birds in rainy season(100 MPS). They were well aware about vaccination as a measure to protect poultry birds from diseases. Respondents possessed knowledge about major poultry diseases i.e. Ranikhet and Foulpox to the lesser extent (29.82 MPS) and they were not at all aware of the means by which disease spread in poultry i.e. through virus and bacteria.

\section{Management}

Sound management practices are very essential to optimize production. Scientific poultry management aims at maximizing returns with minimum investment. The data contained in the table 1 further indicate that the respondents possessed good knowledge about the essential requirement of the poultry shade i.e. there should be proper air and light in the shade. The respondents were not so aware about the standard size of poultry shade (35.08MPS), use of lime when bed gets wet (24.56 MPS) whereas they were well aware of daily cleaning of poultry shade (100 MPS). 


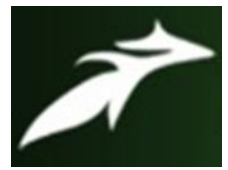

Rashmi Dave et al, International Journal of Advances in Agricultural Science and Technology,

Vol.7 Issue.11, November-2020, pg. 91-99

ISSN: 2348-1358

Impact Factor: 6.057

NAAS Rating: 3.77

Table 2: Overall knowledge of the respondents related to poultry farming

\begin{tabular}{|c|l|c|c|c|c|c|}
\hline \multirow{2}{*}{ S.N } & \multirow{2}{*}{ Components } & \multicolumn{4}{|c|}{ Mean Per cent Score } & \multirow{2}{*}{ Rank } \\
\cline { 3 - 7 } & & Banswara & Dungarpur & Udaipur & Total & \\
\hline 1. & Breeding & 80.00 & 56.32 & 52.63 & 62.98 & I \\
\hline 2. & Feeding & 44.74 & 36.18 & 37.50 & 39.4 & IV \\
\hline 3. & Health care & 61.65 & 60.15 & 60.15 & 60.65 & II \\
\hline 4. & Management & 55.56 & 50.29 & 50.88 & 52.24 & III \\
\hline & Overall MPS & & & & & \\
\end{tabular}

Data regarding overall knowledge of the respondents in Table 2 indicate that respondents possessed more knowledge about breeding practices (62.98 MPS) followed by health care practices (60.65 MPS). The knowledge regarding management and feeding practices were ranked third and fourth respectively. Reason of less knowledge of feeding practices in poultry birds may be that respondents were trained 3-4 years back through learning by doing method. That time practically they learnt about making poultry feed by mixing recommended quantity of different ingredients but after that due to unavailability of these ingredients at their local level and also they found it complex to make at home therefore majority of the them used to bring readymade mixture for feeding. Some of them have forgotten as they had not practiced these activities since long time and they had not spent money to purchase feeder. 


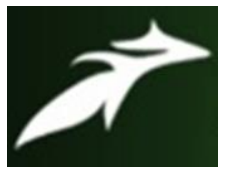

Rashmi Dave et al, International Journal of Advances in Agricultural Science and Technology,

Vol.7 Issue.11, November-2020, pg. 91-99

ISSN: 2348-1358

Impact Factor: 6.057

NAAS Rating: 3.77

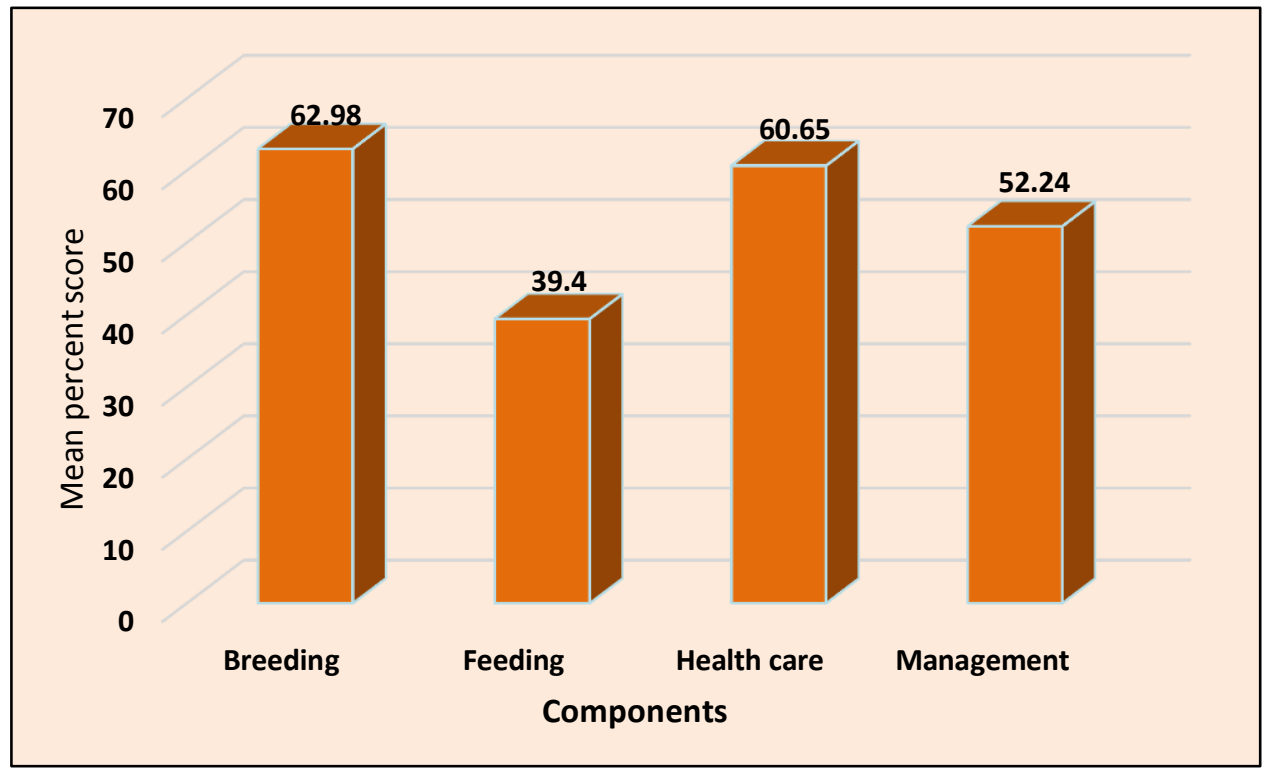

Fig. 1: Component wise knowledge of the respondents regarding poultry production

\section{Conclusion}

It is concluded from the study that Krishi Vigyan Kendras are promoting entrepreneurial activities for economic empowerment of tribal women. Regarding poultry production entrepreneurial activity it was found that majority of the tribal women had average knowledge in overall poultry production activity. It was found that tribal women possessed more knowledge about breeding practices and health care practices as compared to management and feeding practices.

\section{References}

[1]. Akhter, J., Asiwal, B. L. and Hussain, A. 2013. Knowledge and Adoption of Animal Husbandry Practices among the Farmers of Sikar District of Rajasthan. Indian Journal of Extension Education and Rural Development. 21: 196-199.

[2]. Bhumra,H., Goyal, T. C. and Punjabi, N.K. 2018. Knowledge of Dairy Farm Women Regarding Scientific Management of Dairy Animals in Udaipur District. Indian Journal of Extension Education \& Rural Development. 26: 82-88.

[3]. Dar, P. A., Prajapati, K.B. and Parmar D.V. 2016. A study on socio- economic aspects, feeding and breeding practices of goat keepers prevailed in the Tribal area of Banaskantha District of North Gujarat. A 


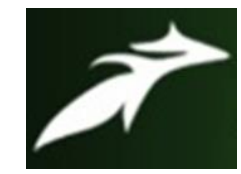

Rashmi Dave et al, International Journal of Advances in Agricultural Science and Technology,

Vol.7 Issue.11, November-2020, pg. 91-99

ISSN: 2348-1358

Impact Factor: 6.057

NAAS Rating: 3.77

Journal of Life Sciences. 73: 75-88

[4]. Munde, S.S., Bhosale, M.B., Poul, S.P. and Mule, R.S. 2009. Feeding practices at commercial goat farming and its effect on growth of kids in Prabhani. The Asian Journal of Animal Science. 4(1): 79-81.

[5]. Naruka, K. and Kailash. 2015. Health Care Practices of Sheep in Jodhpur District of Rajasthan. Indian Journal of Fundamental and Applied Life Sciences. 5 (2): 119-121.

[6]. Nikita. Rao, P.S., Deepali. and Meena, G.L. 2018. Economics of Poultry Enterprise in Rajasthan. Indian journal of extension education and rural development. 26: 40-44.

[7]. Rewani, S., Tochhawng, L. and Ranjan, S .2015.Economic Empowerment of Women through Livestock Based Entrepreneurial Activities of Self Help Groups. Indian Research Journal of Extension Education. Retrived from https://www.researchgate.net.

[8]. Sabapara, G.P., Deshpande, S.B., Kharadi, V.B. and Malik, P.K. 2010. Housing and feeding management practices for goat followed in South Gujarat. Indian Journal of Animal Science. 4(80): 385-387.

[9]. Saha, D., Afzal, H. A. and Abdul, H. 2010. Livestock Farmers' knowledge about Rearing Practices in Ganderbal District of Jammu \& Kashmir. Indian Research Journal of Extension Education. 10(2): 15-19.

[10].Satyanarayan, K. and Jagadeeswary, V. 2010. A study on Knowledge and Adoption behavior of livestock farmers. Indian Journal of Animal Research. 44:100-106.

[11].Saha, D., Afzal, H. A. and Abdul, H. 2010. Livestock Farmers' knowledge about Rearing Practices in Ganderbal District of Jammu \& Kashmir. Indian Research Journal of Extension Education. 10(2): 15-19.

[12].Yogamani, K. S. 2013. Knowledge and Adoption of Improved Dairy Management Practices by Farm Women of Community Milking Centres. An unpublished M.Sc. thesis submitted to University of Agricultural Sciences GKVK, Bangalore. 